\title{
Balanced Score Card Approach for Better Shari'ah Corporate Governance
}

\author{
${ }^{1}$ Sheila Nu Nu Htay and ${ }^{2}$ Syed Ahmed Salman \\ ${ }^{1}$ Institute of Islamic Banking and Finance, International Islamic University Malaysia, Malaysia \\ ${ }^{2}$ IIUM Institute of Islamic Banking and Finance, International Islamic University Malaysia, Malaysia \\ Kuala Lumpur Campus 205 A, JalanDamansara, Damansara Heights 50480 Kuala Lumpur, Malaysia
}

Received 2013-08-01, Revised 2013-08-28; Accepted 2013-10-23

\begin{abstract}
Islamic financial institutions have emerged due to the non-Shari'ah compliant nature of conventional financial from interest, uncertainty, gambling and prohibited activities from the Islamic perspective. In order to achieve the mission of Shari'ah compliance, organizations such as Accounting and Auditing Organization for Islamic Financial Institutions, Islamic Financial Services Board and countries like Malaysia have provided Shari'ah governance guidelines. However, there are some court-cases regarding non-Shari'ah compliant issues and consequently, this has tarnished the reputation of the Islamic financial institutions. There is no guideline on Shari'ah performance measures available to find out to what extent Islamic financial institutions meet its mission. This study tries to fulfill the needs of the industry by providing the balanced score card for Shari'ah governance. This proposed score card is designed based on the concepts of accountability, responsibility, independence and competency of the Shari'ah board members. It suggests measures how any Islamic financial institutions discharge their fiduciary duty towards shareholders, depositors, participants of Islamic industry. The main drive towards Islamic financial institutions is to provide fair and just financial system free insurance, borrowers and society with the expectation of long-term success of the institutions within the Shari'ah framework. The proposed balanced score card is developed based on the opinions of 7 representatives from Islamic banks and 5 representatives from Takaful (Islamic Insurance) Operators. It is expected that this score card can be used as a platform for improving the Shari'ah corporate governance of Islamic financial institutions.
\end{abstract}

Keywords: Balanced Score Card, Islamic Financial Institutions and Shari'ah Governance

\section{INTRODUCTION}

Conventional financial institutions involve the elements of interest, gambling, uncertainty and prohibited elements from the Islamic perspective. Consequently, Muslims scholars come with an alternative system, i.e., creation of Islamic financial institutions. The mission of these institutions is to ensure that their business activities are free from unfair and unjust elements for the betterment of all involved parties regardless of the religion. In order to achieve this mission, Islamic financial institutes are recommended to adopt Shari'ah governance framework.
When the history of corporate governance is examined, it emerged with the birth of the corporation however it becomes an attractive issue to the corporate failures such as Enron, Swissair, the Worldcom, Global Crossing Ltd., Healthsouth, Pamalat, Jinro Ltd and Tyco international companies (Htay et al., 2013). Many countries and organizations have provided the guidelines to be followed by the top corporate players to create the conducive business environment. In the case of Islamic Financial Institutions (IFIs), they are recommended to follow Shari'ah governance guideline issued by (AAOIFI, 2010; IFSB, 2009) in addition to the conventional corporate governance guidelines. Thus, the ic Banking and Finance, International Islamic University Malaysia, Kuala Lumpur campus 205 A, JalanDamansara, Damansara heights 50480 Kuala Lumpur, Malaysia 
unique nature of IFIs is its compliant nature of Islamic principles compared to conventional financial institutions. However, there are a few court cases that have tarnished the reputation of IFIs regarding its compliance with Islamic principles. Islamic financial industry is not matured compared to the conventional industry and due to the fast growing industry, there are a lot of rooms to improve and the existing guidelines and Acts are not that comprehensive enough to cater the current needs of IFIs. For example, Malaysia has Islamic Banking Act 1983 and the Takaful Act 1984. Now, the government is introducing the new Islamic Financial Services Act (IFSA) 2012 to statutorily enforce the management of Shari'ah non-compliance risk and to ensure that IFIs' aim, operation, business, affairs and activities are Shari'ah-compliant at all times (http://biz.thestar.com.my/news/story.asp?file=/2013/2/6 /business/12675789\&sec=business).

To the extent of the researchers' knowledge, there is no specific measurement or guideline to assess the Shari'ah governance performance of IFIs and to link the performance measurement indicators, objectives and mission of IFIs.

Therefore, the objective of this research is to propose the balanced score cared for Shari'ah governance of IFIs.

\subsection{Conventional Corporate Governance}

The issue of corporate governance is not new. It emerged with the birth of corporations. The corporation which is known today, i.e., the profit oriented entities, originated in England and it has highest quality of corporate governance standard (CA, 2013; Kasim et al., 2013). According to Tricker (2012), although corporations in England emerged at the end of the nineteenth century, the phrase "corporate governance" was scarcely used until the 1980s and the literature on corporate governance is less than half a century old. Directors as the agents of the corporation need to monitor the performance of the companies on behalf of the shareholders and hence, the role of the directors is important (Htay, 2012).

Many theories (e.g., agency theory) and corporate guidelines suggest that the best way to monitor directors is by having a good corporate governance system, thus many corporate laws require it. Corporate governance is defined in different ways. According to Jensen and Meckling (1976), "corporate governance is a complex system of control mechanisms supposed to influence management behavior in order to guarantee a high value of the owners' equity in the firm". The definition in the Cadbury report from the UK, 1992 is more role-oriented and it mostly stresses the rights of the shareholders. This report defines corporate governance as "a system by which companies are directed and controlled". Boards of directors are responsible for the governance of their companies. The shareholders' role in governance is to appoint the directors and the auditors and to satisfy themselves that an appropriate governance structure is in place. The responsibilities of the board include setting the company's strategic aims, providing the leadership to put them into effect, supervising the management of the business and reporting to shareholders on their stewardship. The board's actions are subject to laws, regulations and the shareholders in a general meeting.

All the definitions stated above are either too general or focus on one party. The definitions do not take into consideration the needs of the other stakeholders. Their limitations seem to be improved by the definition provided by the OECD (2004). If defines corporate governance as "a set of relationships between a company's management, its board, shareholders and other stakeholders". It further states that "the corporate governance framework depends on the legal, regulatory and institutional environment and other factors such as business ethics and corporate awareness of the environmental and social interests of the communities in which a company operates". In addition to the OECD (2004), the definition of corporate governance given by Solomon (2010) also highlights the accountability and corporate social responsibility towards the stakeholders. They define that corporate governance is "the system of checks and balances, both internal and external to companies, which ensures that companies discharge their accountability to all their stakeholders and act in a socially responsible way in all areas of their business activities".

Summarizing the definitions above, it could be assumed that the main player in the above mentioned parties is the board of directors and the corporate governance system is a guide that the directors should follow in the best interests of all parties. Moreover, the above definitions basically describe the accountability or responsibility of the board of directors towards the shareholders, in particular and the stakeholders, in general.

\subsection{Shari'ah Corporate Governance}

When the corporate governance system is looked at from an Islamic perspective, it should incorporate Islamic teachings. The role of good Shari'ah governance must be founded on the dual accountability, i.e., accountability to God and human being (Kasim et al., 2013). It is expected that IFIs have additional accountability towards God, compared to conventional financial institutions. 
Similar to the conventional aspect, Shari'ah corporate governance focuses on the role and responsibility of the Shari'ah board members to ensure that the whole activities of IFIs are in line with Islamic principles. In other words, Shari'ah governance concentrates more on the accountable, just and fair aspect of corporate governance as suggested by the conventional corporate governance. There are many countries such as Malaysia and Indonesia and international organizations such as (AAOIFI, 2010; IFSB, 2009) have provided guidelines of Shari'ah governance.

These frameworks emphasize on the accountability, responsibility and ethicality of Shari'ah board members. They highlight the importance of objective judgment in discharging responsibilities. They require that Shari'ah board members shall possess the necessary competency and skills in performing their duties and must be trustworthy and keep the confidential information of the IFIs that they are advising. Thus, the purpose of Shari'ah governance framework is to ensure that all IFIs' operations and business activities are in accordance with Islamic principles, to provide a comprehensive guidance to the Shari'ah board members, Shari'ah Committee and management of the IFI in discharging its duties in matters relating to Shari'ah and to highlight the functions relating to Shari'ah review, Shari'ah audit, Shari'ah risk management and Shari'ah research.

\subsection{Important Role of Balanced Score Card in Enhancing Governance Practices}

Balanced score card is defined as "a strategic planning and management system that is used extensively in business and industry, government and nonprofit organizations worldwide to align business activities to the vision and strategy of the organization, improve internal and external communications and monitor organization performance against strategic goals (https://www.balancedscorecard.org/BSCResources/Abo uttheBalancedScorecard/tabid/55/Default.aspx)". It was initiated by Robert and Norton (2006) as a performance measurement framework by inserting the strategic nonfinancial performance measures to traditional financial metrics in order to provide a more 'balanced' view of organizational performance. This score card is widely used in the United States of America. The board Balanced Scorecard program starts with an Enterprise Scorecard which shows the clear guide on how to achieve the mission through objectives, targets and performance measurements. Thus, it is a flexible tool to evaluate the performance of the board of directors from the different aspects.

\section{RESEARCH METHODOLOGY}

This study is based on the quality research. Both primary and secondary data are used in this study. In collecting the primary data, interview has been conducted by asking the representatives from the Islamic banks and Takaful operators. In the case of secondary, articles, books and online internet resources are used to find out the most relevant and recent literature related to this research. Delphi technique is employed for interview. This technique is employed basically to gather a collective view from a panel of experts on issues where opinions are important and the information available is little or no definite evidence found (Sekaran and Bougie, 2010). This approach therefore was considered to be very appropriate for carrying out this research. According to Sekaran and Bougie (2010) in a delphi study, the participants reply to questionnaires in successive rounds until the researcher acquires the consensus, or when a certain level of agreement is attained.The interviews are conducted in an iterative mode, with the aim of reaching a certain consensus on the issues at hand.The iterative component in this technique offers the researcher with opportunities to present the opinions of each expert to the other experts for their feedback. This, in turn, facilitates in coming up with a more consistent view on the issues deliberated and serves up the objective of the research adequately.

The interview questions are developed based on The interview questions have been constructed by adopting the Kaplan's Balanced score card concept and referring the past literature as well as the Shari'ah governance guidelines issued by AAOIFI (2010); IFSB (2009) and BNM (2013).

\section{PROPOSED BALANCED SCORE CARD FOR SHARI'AH CORPORATE GOVERNANCE}

Since the ultimate purpose of IFIs should be to provide the Shari'ah compliant products and to ensure that all the activities of IFIs are in line with Islamic teachings. Seven representatives from Islamic banks and five representatives from Takaful Operators are interviewed. After the third round of interview, the above score card is resulted.

The proposed balanced score card (Fig. 1) is based on the concept of the dual accountability and it covers six aspects of Shari'ah corporate governance performance, namely, depositors and Islamic insurance contributors, shareholders, borrowers, society, internal Shari'ah compliant process and long term success and growth. 


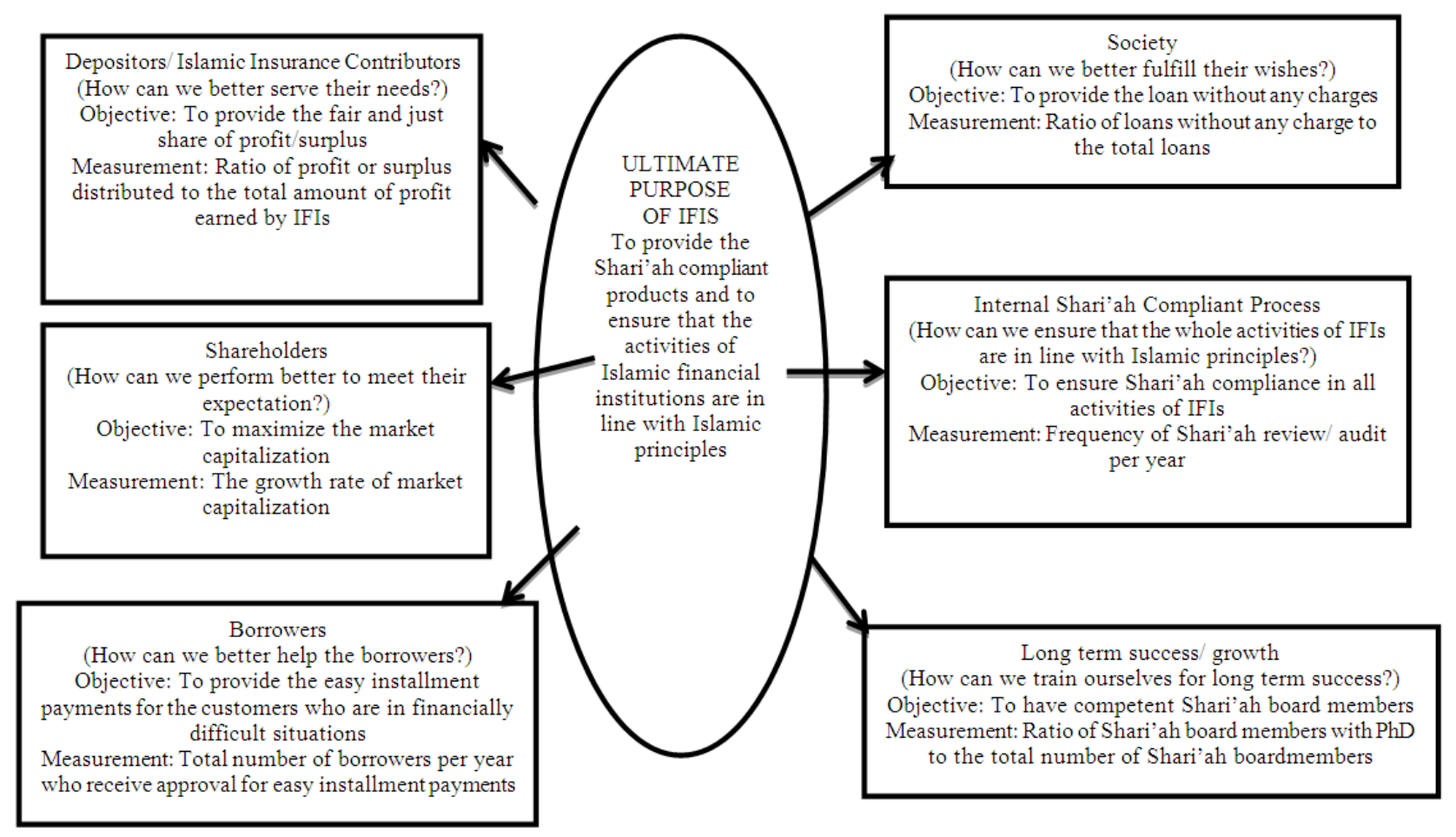

Fig. 1. Proposed balanced score card

The first aspect of the balanced score car covers the depositors/Takaful Contributors since they are the main sources of income for Islamic Financial Institutions (IFIs). The institutions should think how to serve their needs better. Thus, the objective of IFIs should be to provide the fair and just share of profit/surplus to them. It can be measured by "the ratio of profit or surplus distributed to the total amount of profit earned by IFIs".

Secondly, shareholders are the owners of the IFIs and thus they should think how to perform better to meet the expectation of the owners. The objective of IFIs for the shareholders should be to maximize the market capitalization and it can be measured by "the growth rate of market capitalization over the years".

The third aspect of balanced score card covers the borrowers to whom IFIs should try to help their best in order to meet their financing needs. The respective objective should be to provide the easy installment payments for the customers who are in financially difficult situations and it can be measured by "total number of borrowers per year who receive approval for easy installment payments".

The fourth item emphasized in our proposed score card is society at large. IFIs should think how to fulfill their wishes, for instance to provide the loan without any charges and it can be measured by "ratio of loans without any charge to the total loans".

The fifth is related to Shari'ah compliant process to ensure that IFIs are operating within the Shari'ah framework and it can be measured by "frequency of Shari'ah review/audit per year". Finally, the sixth aspect looks at the long term success and growth of the IFIs by having competent Shari'ah board members and it is proxies by "ratio of Shari'ah board members with $\mathrm{PhD}$ to the total number of Shari'ah board members".

\section{CONCLUSION}

This study proposes the balanced score card for Shari'ah corporate governance of Islamic financial institutions. Delphi technique is used in interviewing the representatives from Islamic banks and Takaful operators. The interview questions have been constructed by adopting the Kaplan's Balanced score card concept and referring the past literature as well as the Shari'ah governance guidelines issued by (AAOIFI, 2010; IFSB, 2009; BNM (2013). This study enlightens the very foundation concept of Islamic financial institutions. 
Compared to the conventional financial institutions, the Islamic financial institutions have additional task to fulfill, i.e., to meet the needs of various expectations from the related parties while complying with Shari'ah. Thus, the researchers believe that this unique Shari'ah compliant nature is the main distinguishing factor between conventional and Islamic financial institutions. The later institutions must be able to perform in order to meet the mission. The proposed score card is founded on the opinions of two interviewees from the Islamic financial institutions. It is expected that this score card will be the interests of Shari'ah advisors, industrial players, regulators, researchers and general public. This conceptual balanced score card can be used to measure the performance of Shairah governance and it can be used a platform to improve further.

\section{REFERENCES}

AAOIFI, 2010. Accounting auditing and governance standards for Islamic financial institutions. AAOIFI Bahrain.

BNM, 2013. As Malaysia's Central bank, bank Negara Malaysia promotes monetary stability and financial stability conducive to the sustainable growth of the Malaysian economy. Bank Negara Malaysia.

CA, 2013. Principles and better pratices Corporate Governance in Common wealth Authorities and Companies. Commonwealth of Australia.

Htay, S.N.N., 2012. Corporate governance and strategic information disclosure in malaysian listed banks: Panel data analysis. Int. Rev. Bus. Res., 8: 196-210.
Htay, S.N.N., S.A. Salman and S. Ibrahim, 2013. Invisible hands behind the corporate governance practices in Malaysia. World J. Social Sci., 3: 119-135.

IFSB, 2009. Guiding principles on shari'ah governance systems for institutions offering Islamic financial services. Islamic Financial Services Board.

Jensen, M.C. and W.H. Meckling, 1976. Theory of the firm: Managerial behavior, agency costs and ownership structure. J. Finance Econ., 3: 305-360. DOI: 10.1016/0304-405X(76)90026-X

Kasim, N., S.N.N. Htay and S.A. Salman, 2013. Shariah governance for islamic capital market: a step forward. Int. J. Educ. Res., 1: 1-14.

OECD, 2004. Principles of Corporate Governance. 1st Edn., OECD Publishing, Paris, ISBN-10: 9264015973, pp: 66.

Robert, S. and D.P. Norton, 2006. Creating the Office of Strategy Management. Working Knowledge.

Sekaran, U. and R. Bougie, 2010. Research Methods for Business: A Skill Building Approach. 5th Edn., John Wiley and Sons, Chichester, ISBN-10: 0470744790, pp: 488.

Solomon, J., 2010. Corporate Governance and Accountability. 3rd Edn., John Wiley and sons, pp: ISBN-10: 1119959306, pp: 440.

Tricker, Bob, 2012. Corporate Governance: Principles, Policies and Practices. 2nd Edn., Oxford University Press, Oxford, ISBN-10: 0199607966, pp: 546. 